\title{
Economic Contribution in the Management of Solid Waste Policy Processing Water on Improvement of Fish Processing Revenues
}

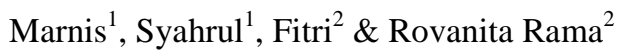 \\ ${ }^{1}$ Faculty of Economics, State University of Riau, Indonesia \\ ${ }^{2}$ Faculty of Fisheries and Marine Affairs, State University of Riau, Indonesia \\ Correspondence: Priyono, Graduate Program Master of Management, University Bina Darma, Palembang, \\ Indonesia. Tel: 812-1697-4878. E-mail: priyono.unu_sidoarjo@yahoo.com
}

Received: November 28, 2017

Accepted: January 2, 2018

Online Published: January 10, 2018

doi:10.5539/ijef.v10n2p95

URL: https://doi.org/10.5539/ijef.v10n2p95

\begin{abstract}
This study aims to analyze the economic contribution in the environmental management of solid waste processing of catfish to increase income of fish processing in Koto village Kampar regency Riau.

The research method used is the method of exploitation of solid waste processing and case studies with respondents processing catfish (fillet fish, salai and salted fish). Data were collected using questionnaires on business actors, and solid waste processing trials (meat waste, fish head, fish bone, belly fat and edible offal or stomach). The waste is processed into raw material for food and feed industries that meet the quality standard of Indonesian National Standard (SNI) and calculated its economic value include business analysis (Gross Benefit Cost Ratio), Profitabilty Ratio, and IRR and environmental management scenario of catfish fish industry. The data obtained will be homogenized data and then tabulated and analyzed descriptively quantitative.

The results showed that the net production technology capable of producing industrial raw materials in the form of fish meal (fish protein concentrate (KPI), fish oil, bone meal and fish skin chips with the Indonesian National Standard.
\end{abstract}

Keywords: economic contribution, environmental management, fish processing income

\section{Introduction}

The current issue of environmental management has become an intense concern, due to the rapid development of industrialization causing environmental damage and pollution cases (Amine, 2003). Further Damayanti et al. (2004) Muqorobin et al. Stated that the high intensity of research on environmental management issues has triggered increased awareness of producers to care in the production process that is environmentally friendly or better known as green product. Environmental management mechanisms include the ability to realize, grow, develop, raise awareness and responsibility of the community, decision makers and business actors in environmental management. In addition, in environmental management needs to guarantee the maintenance of environmental carrying capacity, environmental information and implement environmentally friendly science and technology.

Currently awareness of environmental management is growing, this has a positive impact for all parties. Through the application of good environmental management can provide benefits of physical environmental protection, forming a culture of sustainability and instilling moral values and trust between elements (Purwanto, 2004), This shows that research on environmental management is very important the concept of clean production in accordance with the philosophy of "prevention is better than cure". Therefore the concept of clean production is universal and in general the net production aims to reduce the level of pollutant emissions and the production of waste from its source, thereby reducing the negative impact on the environment (Pickett \& Ozaki, 2008). This concept as a whole includes several modifications to each stage of production, so that the reduction of the use of raw materials, energy and waste generated.

Initially fish oil gets special attention because of high vitamin A and D levels. Further development, fish oil is known to contain omega-3 fatty acids that have a role for health (Estiasih, 2009). In Scotland fish oil is used to help bone growth and central nervous development. In England, France, Germany, and Netherlands cod liver oil is used to cure lung, rheumatic and other bone diseases. Various diseases can be cured because fish oil contains 
omega-3 fatty acids (Nurjanah, 2002).

In every process of fish processing, it will always produce the product and waste. The resulting waste is directly disposed of so that it is not part of the minimization of waste. Waste minimization is an activity of preventing and reducing the material to improve the quality of final waste resulting from various processes that last up to the final disposal site (OECED, 2000).

To minimize waste, according to Indrasti et al. (2009) can be done by: 1) classifying or identifying waste by group, 2) waste separation, and 3) sewage treatment. In minimizing waste, human resources are a major factor, because it is these human resources that can manage the waste.

Pangasius hypopthalmus is a type of freshwater fish that is taxonomic according to Saanin (1968) including Pisces class, Teleostei subclass, Ostariophysi Order, Family Pangasidae, Pangasius Genus and Pangasius sutchi and Pangasius hypopthalmus Species. The morphological characteristics of the Siamese catfish are as follows: elongated and flat body, terminal mouth (slightly on the bottom) with four barbells, the dorsal fin has additional fins (fin adifose), there is a curved line from the head to the base of the caudal fin, caudal fins with white edges, blackish gray and white anal fin with a black line in the middle (Sumantadinata, 1983).

Fats and oils are one group belonging to the lipid group, ie organic compounds found in nature and insoluble in water, but soluble in non-polar organic solvents, eg diethyl ether $(\mathrm{C} 2 \mathrm{H} 5 \mathrm{OC} 2 \mathrm{H} 5)$, chloroform $(\mathrm{CHCl} 3)$, benzene and hydrocarbons others. Fats and oils may dissolve in the above-mentioned solvents because fats and oils have the same polarity as the solvents (Herlina \& Ginting, 2002).

Fish lipids are biomolecules composed beneath the skin of fish, around delicate, vital body organs and filling empty cavities in the tissues. The lipids include fat, oil, phosphatides, sterols and stroids (Syahrul et al., 2015).

Food fat derived from animal products there can be a lowering of plasma cholesterol is a group of unsaturated fatty acids consisting of omega- 3 and omega- 6 fatty acids, which are essential fatty acids that have double bonds

\section{Research Methods}

\subsection{Materials and Tools}

The main raw material used in this research is the solid waste processing of Siamese catfish (Pangasius hypopthalmus) cultivated in Koto Mosque Kampar village, Riau. It also used materials processing solid waste catfish processing into functional components of food and chemicals for quality analysis (hexane, filter paper, $\mathrm{K} 2 \mathrm{~S} 04, \mathrm{H} 2 \mathrm{~S} 04, \mathrm{HgO}, \mathrm{NaOH}, \mathrm{H} 3 \mathrm{~B} 03$, Hel, and $\mathrm{Na} 2 \mathrm{~S} 203$ and packaging materials. also materials for the questionnaire and others.

The tools used for the processing of solid waste include blenders, flour, oil separator, glass bottle, aluminum pan, stove, filter, and dryer oven.

This research uses survey method and experiment, that is conducting survey of environmental condition of catfish processing business before managed and after managed; while the experiment is to conduct solid waste processing trials into raw materials for food and feed industries such as fish protein concentrate / fish meal, bone meal, fish oil, and crude protease enzymes.

\subsection{Implementation of Research}

The target of this research is the catfish processor in Koto Mosque village and its surrounding area includes the processing unit of marinating, fumigation, and fish fillet. Aspects of the study include: overview of research area, socio-economic profile-demographic of fish processor, production profile of fish processing business, and, public perception toward solid waste existence produced by catfish processing industry.

Analyzer used in this research is StatisticDiskriptif qualitative and quantitative. Descriptive method according to Umar (2005) is a research method to create a picture of the situation or event so that this method will accumulate basic data.

\subsection{Data Collection Method}

The data used to be analyzed is primary data and secondary data. Primary data obtained through observation and survey of respondents who are sampled assisted by the questionnaire. Interviews were conducted directly to the fish processors by means of question and answer. Primary data collected, in the form of:

1). Profile of fish processing business:

2). Factual condition of fish processing environment, especially solid waste disposal of fish processing.

3). Public perception about fish processing business on the existence of solid waste produced by catfish 
processing unit.

While secondary data is supporting data obtained from results of interviews with related institutions. Methods of data collection research conducted is to use questionnaires, interviews. Observation, documentation and forum group discussion (FGD).

\subsection{Data Analysis}

The analysis is done qualitatively and quantitatively used in analyze:

1). Social-demographic profile of fish processors

The social-demographic analysis of fish processors is intended to know fish processing characteristics seen from: age, education level, number of family members, long to be processors, income, and effort that has been done so far in the field of fish processing.

\section{2). Profile of fish processing business}

This analysis is intended to find out the profile of fish processing production that is being sampled in this research, including: number of labor, raw material of processing, facilities and infrastructure needed, length of processing time, number of people involved in processing and marketing location.

\section{3). Advantages}

Profit analysis is intended to know the pattern of income and expenditure and the amount of profit in the fish processing business. Profit is the difference between total revenue and costs. Indicators seen are: average production ( $\mathrm{kg} /$ day), average total revenue ( $\mathrm{Rp} / \mathrm{day})$, total expenditure $(\mathrm{Rp})$ and business profit (Rp/day). It will also be seen the ratio of total revenue and total cost (R/C ratio). Profit according to Freddy (2011) states that the Total Revenue (TR) is derived from the multiplication of production (Q) with the average price/Kg (P), while Total Cost (TC) is derived from the sum of all the costs required in the business trade and processing.

Benefits can be written as follows (Freddy, 2011): $\mu=$ TR-TC

Information: $\mu=$ Profit (revenue) $\mathrm{TR}=$ Total Revenue (total revenue) $\mathrm{TC}=$ Total Cost (total cost)

\subsection{Research Stages}

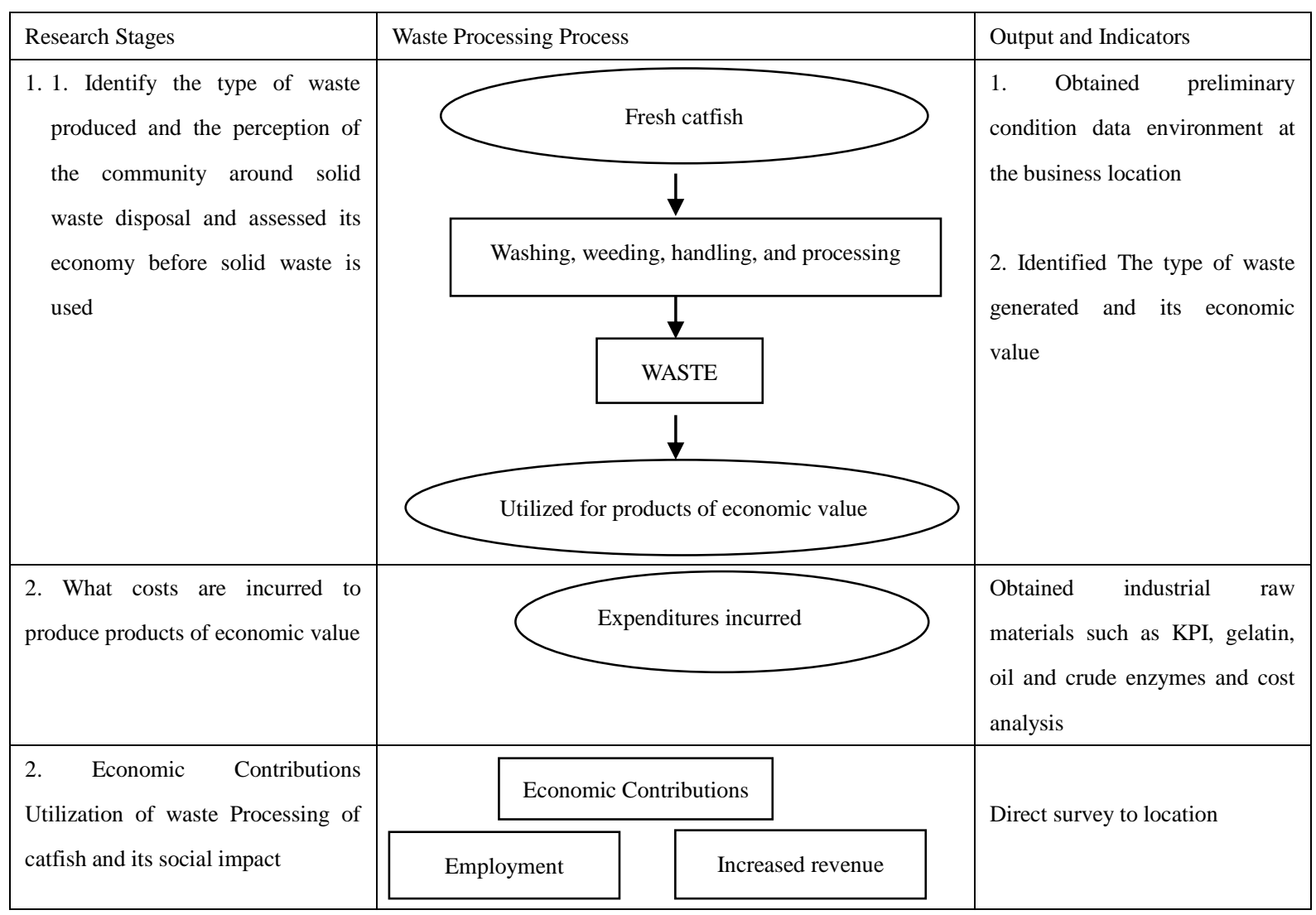




\section{Results and Discussion}

\subsection{Social Demographic Profile of the Population}

The population is a number of people who reside in a certain area and according to Mubyarto (2002) Population is a number of people who reside in a region at a certain time and is the result of the demographic process of natalitas, mortality, and migration. Based on data obtained from the Head Office of Koto Mosque Village, the population of this region in 2013 was recorded 1,827 people (507 families). The composition of the number of male and female population did not differ much. To explain the number of population by sex can be seen in Table 1.

Table 1. The number of residents of Koto Mosque village by sex of the year 2013

\begin{tabular}{lccc}
\hline No. & Gender & Amount (soul) & Percentage (\%) \\
\hline 1. & Man & 939 & 48,60 \\
2. & Women & 888 & 51,40 \\
\cline { 2 - 5 } & amount & 1.827 &
\end{tabular}

In Table 1 it can be seen that the number of male and female population can be said is relatively no different although the difference is 51 soul. While by age group can be seen in Table 2.

Table 2. The number of residents of Koto Mosque village by age group 2013.

\begin{tabular}{lccc}
\hline No. & Age Group (year) & Amount (soul) & Percentage (\%) \\
\hline 1. & $0-5$ & 214 & 5.25 \\
2. & $6-20$ & 411 & 22.50 \\
3. & $21-45$ & 743 & 40.67 \\
4. & $46-70$ & 568 & 31.09 \\
5. & $>70$ & 9 & 0,49 \\
\hline & amount & 1.827 & 100 \\
\hline
\end{tabular}

Source: Monograph of Koto Mosque Village, 2013.

Table 2 above shows that population groupings by age group are based on groups of under five (0-5 years), primary and secondary education students (6-20 years old), very productive age (21-45 years), productive age (46-70 years) and less productive or elderly (> 70 years). Furthermore, based on the livelihood, the people of Koto Mosque village consist of farmers, civil servants. breeders, fish farmers and entrepreneurs. For more details can be seen in Table 3.

Table 3. The number of residents of Desa Koto Mosque based on the livelihood of the year 2013

\begin{tabular}{llcc}
\hline No. & Livelihood & Amount (soul) & Percentage (\%) \\
\hline 1. & Farmers / Planters & 309 & 43.95 \\
2. & government employees & 82 & 11.66 \\
3. & Breeders & 14 & 1.99 \\
4. & Fisheries (Fish Cultivators) & 257 & 36.56 \\
5. & Entrepreneurship & 41 & 5.83 \\
\hline & amount & 703 & 100 \\
\hline
\end{tabular}

Source: Monograph of Koto Mosque Village, 2013.

In Table 3 above shows that livelihoods in the fishery sector occupy the second position after farmers / planters. In fishery sector, fishery main activity is catfish culture business in pond. The village of Koto Mosque is known as state Patin, because almost every house is a catfish pond, meaning "there is no house without a pond".

\subsection{Catfish Culture (Pangasius Hypopthalmus)}

Catfish culture business activities in Koto Mosque Village has been done since the Koto long Dam is a reservoir for Koto long power plant. Generally catfish breeding business is done in the pond, and according to its 
development the number of catfish farmers in the pond is increasing. This can be seen from the number of fish ponds owned by the local community, where almost every house has a pond of catfish culture so that it says "no house without a pond".

The success of catfish culture in this pond is supported by sufficient water resources available throughout the year, and support from various parties, both government and private parties and universities. Therefore, catfish culture business in Koto Mosque Village has become a business as a livelihood dominant, because most women do not directly participate fish cultivation effort. To empower women, some catfish processing business give opportunity to women to work in catfish processing business unit. According to information from patin fish processing business from fish fillets, fish origin, salted fish and others, that solid waste generated from catfish processing unit leaving solid waste in the form of head, bone, belly fat and meat tetelan about 4-6 tons per week . Thus the solid waste generation is $15-24$ tons per month.

The generation of solid waste is increasingly causing unfavorable environmental impacts, especially the smell of rotting fish. This is what encourages researchers to study from the economic aspects of economic contribution in the utilization of solid waste processing catfish.

\subsection{Business Profile of Patin Fish Processing}

As mentioned earlier, Koto Mosque village is one of the villages in XIII Koto Kampar sub-district, Kampar regency, Riau province, Indonesia. In Koto Mosque, there are fish ponds as many as 916 fish ponds with an area of $52 \mathrm{Ha}$, with average production of fresh catfish 8-10 tons per day. In addition to producing live catfish, Koto Mosque Village also process catfish into fish fillets, salai (smoked fish), crackers, meatballs, abon and nuggets. Catfish processing business is centered in Post-harvest, Center specially built for catfish processing business by Riau provincial government and Kampar district. Although catfish processing business centered at Sentra Post-harvest, there is also outside postharvest Sentra. Where there is 1 business unit of catfish fillet and 5 units of salai fish processing business, while outside post harvest center there are 3 units of salai fish processing and I business unit of processed product diversification of catfish fish such as catfish meatballs, fish nugget, fish abon, catfish skin and jerky salai fish.

Of the total production of catfish 8-10 tons per day, processed into fish-based fish based on catfish about 20-50\%. Thereby the result of solid waste processing of catfish is 1-4 ton per day which consist of $10 \%$ tetelan meat, $12 \%$ abdominal fat, $3 \%$ offal, and $75 \%$ bone. Solid waste processing of catfish is mostly discharged into the environment and a small portion used as fertilizer vegetable crops. Whereas this solid waste further processed bilai will be an added value for business people processing catfish in the village Koto Mosque.

\subsection{Analysis of Economic Contribution of Solid Waste Utilization of Fish Processing}

Utilization of solid waste catfish processing can be done with the concept of clean production. The concept of clean production provides an opportunity for fish processing business as a means of control of end-of-pipe and waste management, so that expensive and unproductive investment expenditures can be prevented. In addition, the application of net production can improve the efficiency, profitability, industrial competitiveness, especially the export-oriented products industry. Therefore the main target of the concept of clean production is more emphasized how the acts practiced will generate economic benefits for business actors.

Economic contribution in the application of clean production to fish processing business can be reviewed from 2 aspects, namely: 1) Recovery aspect of raw materials, especially solid organic raw materials in the form of solid waste fish processing can be residual meat on bone fish fillet process, belly fat, head and bone and abdominal contents, and (2) Economic aspects and prevention of environmental pollution. Through the concept of clean production, solid waste generated from the processing can be used to produce industrial raw materials in the form of fish meal (fish protein concentrate), bone meal, fish oil, and crude enzymes. To produce each component of solid waste into a product of economic value required an economic analysis with the necessary indicators in a feasible business feasibility study (Sutrisno, 2007), the indicators are Net Present Value (NPV), Benefit Cost Ratio (BCR), Profitability Index (PI), and Internal Rate of Return (IRR).

\section{a. Net Present Value (NPV)}

NPV is the difference between disbursed expenses and revenues using the social opportunity cost of capital as a discount factor, or in other words the estimated future cash flows that are discounted at this time. To calculate NPV data is needed on the estimated investment cost, operating cost, and maintenance as well as the estimated benefits of the planned project. So the NPV calculation relies on a discounted cash flow technique.

The result of calculation on NPV of the utilization of solid waste processing of catfish can be seen in Appendix 1. From the calculation result, the value of NPV is 1.60 , it means> 0 , then the business is feasible to be 
implemented.

b. Profitability Ratio (PR)

Profitability ratio is a measure to find out how far the effectiveness of management in managing the company. Management effectiveness includes functional management activities, such as finance, marketing, human resources, and operations. The purpose of this ratio is to measure the overall effectiveness of management that can be seen from the benefits generated

The result of calculation on the PR of the utilization of solid waste processing of catfish can be seen in Appendix 1. From the calculation result, the PR value is 2,60 means $>0$, then the effort is feasible to be implemented.

\section{a. Benefit Cost Ratio (BCR)}

Benefit Cost Ratio is one method of investment feasibility. Basically the calculation of this investment feasibility method is more emphasis on the benefits and sacrifice (cost/cost) of an investment, can be a business, or project. In general, the type of invetation that is often used are projects where the benefit is a type of direct benefit, the benefits will be felt directly on the community a lot,

The results of calculations on BCR business utilization of solid waste processing catfish. From the calculation results obtained $\mathrm{BCR}$ value is 1.15 means> 0, then the business feasible implemented.

b. Internal Rate of Return (IRR)

IRR is an indicator of the efficiency level of an investment. A project / investment can be done if the rate of return is greater than the rate of return if investing elsewhere (bank deposit interest, mutual funds and others). IRR is used in determining whether an investment is implemented or not, The result of calculation on IRR of solid waste processing utilization of catfish fish. From the calculation result obtained IRR value is $65,91>18 \%$, hence effort feasible executed.

\section{Conclusions and Recommendations}

\subsection{Conclusion}

From the results of research that has been done can be concluded as follows:

1) The solid waste produced from the catfish processing in Koto Mosque Kampar district is the contents of the stomach, head, fin, tail, belly fat, skin and bone. This solid waste has not been widely used for industrial raw materials such as starch offal, bone meal, fish oil and fish meal.

2) Result of research indicate that clean production technology able to produce industrial raw material in the form of fish meal (fish protein concentrate (KPI), fish oil, bone flour and fish skin chips according to Indonesian National Standard In view of environmental impact analysis and business analysis that is value NPV is 1.60, (Benefit Cost Ratio = 1.15> 1), Profitabilty Ratio of 2.607> 1, and IRR of 65.91>18\%, then the establishment of business utilization of solid waste processing catfish small industry scale is feasible to be implemented .

\subsection{Suggestion}

Based on the analysis of economic contribution made to the utilization of solid catfish processing, the solid waste utilization business is declared eligible to be implemented. Thus, through this business can increase the profit and income for patin fish processing business.

\section{References}

Agus, M., Agus, F., \& Nasir, M. (2011). Environmental Management Problems and Industrialization Issues. National Seminar on Applied Economics Faculty of Economics UNIMUS 2.

Agustono. (1996). Economic Value of Mangrove Forest for Society (Case Study in Muara Cimanuk, Indramayu). Thesis Master of Science (Not Published), Postgraduate Program of IPB, Bogor.

Amine, L. S. (2003). An integrated micro and macro level discussion of global greenissues. Journal of International Management, 9(4), 375-389. https://doi.org/10.1016/j.intman.2003.08.002

Bambang, S. (1994). Financial Statement Analysis. Jakarta: LP3ES.

Barton, D. N. (1994). Economic Factors and Valuation of Tropical Coastal Resources.SMR-report 14/94. Center for Studies of Environment and Resources, University of Bergen, Norway.

Bunce, L. L., \& Kent, R. G. (1998). Coral reef valuation: A rapid socioeconomic assessment of fishing, water-sports, and hotel operations in Montego bay marine park, Jamaica and an analysis of reef 
management implications. World Bank Research Committee Project \#RPO 681-05.

Damayanti, A., Hermana, J., \& Masduqi, A. (2004). Environmental risk analysis of tofu factory waste processing (Pistia stratiotes L.). Purification Journal, 5(4), 151-156.

Fahrudin, A. (2009). Economic Analysis of Coastal Land Management in Subang Regency, West Java. Thesis Master of Science (Not Published), Postgraduate Program of IPB, Bogor.

Freddy, R. (2011). Marketing Research. Gramedia Pustaka Utama, Jakarta.

Husein, U. (2005). Research Methods. Jakarta: Salemba Four.

Iskandar, P. (2002). Macro and Macro economics (2nd ed.). Jakarta: Ghalia Indonesia.

Ministry of Marine Affairs and Fisheries Republic of Indonesia (MMAF). (2001). Country Status Overview (CSO): Exploitation and Trade of Reef Fishery in Indonesia. MMAF, International Marine Alliance (IMA) and Telapak Foundation. Jakarta.

Mubyarto. (2002). People's Economy Inauguration YAE-Bina Swadaya, Jakarta.

Netti, H., Hendra, M., \& Ginting, S. (2002). Fat and oil. Faculty of engineering, major Chemical Engineering, University of North Sumatra, Medan.

Nilasari. (2004). Omega 3 Fatty Acid Analysis From Head Oil Sunglir Fish. Faculty of Fisheries and Marine IPB.

Pass Christophes. (1997). Macroeconomic Theory. Jakarta.

Pickett-Baker, J., \& Ozaki, R. (2008). Pro-environmental products: Marketing influence on consumer purchase decision. Journal of Consumer Marketing, 25(5), 281-293. https://doi.org/10.1108/07363760810890516

Purwanto, A. T. (2002). Analysis of the effect of ISO 14001 implementation on quantitative and qualitative environmental performance indicators using the development of EPE model ISO 14031. Thesis, Institut Teknologi Bandung, Indonesia.

Sadono, S. (2004). Macroeconomic Theory of Introduction. Jakarta: Rajawali Press.

Spurgeon, J. P. G. (1992). The economic valuation of coral reefs. Mar. Poll. Bull., 24(11), 529-536. https://doi.org/10.1016/0025-326X(92)90704-A

Suharsono. (2001). Condition of Coral Reef Resource in Indonesia. Oceanological Research and Development Center, Indonesian Science Agency. Paper presented in International Workshop on the Trade in Stony Corals: Development of sustainable management guidelines. Jakarta, April 9-12.

Suprianto, Mirnailza, \& Syahrul. (2015). Consumer Acceptance Study Against Meatballs Fish Malong (Muarenesox talabon) With Different Binder Material, JOM.

Sutrisno, H. M. M. (2007). Financial Management (1st ed.). Yogyakarta.

Trilaksani, W. E., \& Salamah, M. N. (2006). Utilization of Tuna Fish Waste (Thunnus SP) as a Source of Calcium with Protein Hydrolysis Method. Indonesian Fishery Products Processing Journal, 9(2).

Wallace, C. C., Richards, Z., \& Suharsono. (2001). Regional Distribution Patterns of Acropora and Their Use in the Conservation of Coral Reefs in Indonesia. Indonesian Journal of Coastal and Marine Resources, 4(1), 40-58.

Widadi, R. I. (2011). Preparation and Characteristics of Protein Hydrolyzate from Catfish (Clarias gariepinus) using enzyme Papain. Departemen of Technology of Aquatic Results, Faculty of Fisheries and Marine Science IPB.

Yulianto, A. A. (2006). Fundamentals of Financial Management (Issue 10). Jakarta: Salemba Four.

\section{Copyrights}

Copyright for this article is retained by the author(s), with first publication rights granted to the journal.

This is an open-access article distributed under the terms and conditions of the Creative Commons Attribution license (http://creativecommons.org/licenses/by/4.0/). 